\title{
PENGARUH SOSIALISASI PERPAJAKAN, TARIF PAJAK, SANKSI PERPAJAKAN, DAN KESADARAN PERPAJAKAN TERHADAP KEPATUHAN PELAPORAN SPT TAHUNAN WAJIB PAJAK ORANG PRIBADI (Studi Empiris Pada KPP Pratama Jayapura)
}

\author{
Marisa Setiawati Muhamad ${ }^{1}$ \\ marisasetiawati58@gmail.com \\ Dr. Meinarni Asnawi, SE., M.Si, CBV, CMA ${ }^{2}$ \\ Bill J. C. Pangayow, SE., M.Si., Ak ${ }^{3}$ \\ Jurusan Akuntansi, Fakultas Ekonomi dan Bisnis Universitas Cenderawasih
}

\begin{abstract}
This study aims to analyze the influence of taxation socialization, tax rates, tax sanctions, and tax awareness on tax reporting compliance Annual taxpayer person. Study at KPP Pratama Jayapura. Data collection in this study is to use questionnaires to individual taxpayers in KPP Pratama Jayapura. The sampling technique used in this research is convenience sampling. Data analysis techniques using Partial Least Square (PLS) using Smart PLS 3.0 software. Based on the results of analysis by using PLS test tool shows that there is influence between taxation on taxation awareness. There is an influence between taxation socialization, tax rate and tax awareness on tax reporting compliance annual taxpayer personal person. While the tax sanction does not affect the taxpayer annual reporting of the individual taxpayers. Tax awareness may interfere with the socialization of annual taxpayer's annual reporting compliance.
\end{abstract}

Keyword : socialization of taxation, tax rates, tax sanctions, tax awareness, taxpayer compliance.

\section{PENDAHULUAN}

Pajak sebagai sumber utama penerimaan dalam APBN berkontribusi lebih dari 70\%(Suhendri, 2015). Penerimaan pajak di Indonesia saat ini masih belum maksimal, meskipun memiliki fungsi yang sangat penting. Hal ini tercermin dalam realisasi yang tidak sesuai dengan target. Kota Jayapura sendiri penerimaan pajak pada tahun 2017 mengalami penurunan bila dibandingkan dengan periode yang sama pada tahun 2016. Menurut Kepala Kantor Pajak Pratama (KPP) Jayapura, Bayu setiawan mengatakan, hingga Oktober 2017, pihaknya telah menerima pajak sebesar 43 persen dengan nominasi $\mathrm{Rp} 1,350$ triliun, dari target 84 persen yang diperkirakan hingga akhir Desember target tersebut akan tercapai (Syahriah, 2017).

Tingkat kepatuhan dalam penyampaian Surat Pemberitahuan (SPT) tahunan dan masa secara benar dan tepat waktu merupakan ukuran tingkat kepatuhan wajib pajak yang paling utama. Semakin tinggi tingakat kebenaran dalam menghitung, memperhitungkan, ketepatan menyetor dan menyampaikan Surat Pemberitahuan (SPT) secara benar dan tepat waktu, diharapkan semakin tinggi tingkat kepatuhan wajib pajak dalam melaksanakan dan memenuhi kewajiban pajaknya. Menurut Julianti(2014) mengatakan bahwa semakin tinggi tingkat pemahaman dan semakin luas pengetahuan yang dilakukan dalam sosialisasi maka akan meningkatkan kepatuhan wajib pajak dalam membayar kewajiban pajaknya. Dengan adanya sosialisasi diharapkan Direktorat Jenderal Pajak akan

\footnotetext{
${ }^{1}$ Alumni Jurusan Akuntansi FEB Uncen

${ }^{2}$ Dosen Jurusan Akuntansi FEB Uncen

3 Dosen Jurusan Akuntansi FEB Uncen
} 
memberikan suatu pemahaman akan gambaran penting mengenai pajak dari banyak sisi. Berdasarkan penelitian Suhendri(2015)menyatakan bahwa kepatuhan wajib pajak juga dipengaruhi oleh tarif pajak. Tarif pajak merupakan persentase untuk menghitung jumlah pajak yang terutang. Pemberlakuan tarif pajak mempengaruhi wajib pajak dalam membayar pajaknya. Sanksi perpajakan juga akan mempengaruhi kepatuhan wajib pajak. Menurut Mutia(2014) pelaksanaan sanksi perpajakan diterapkan sebagai akibat tidak terpenuhinya kewajiban perpajakan oleh wajib pajak sebagaimana yang telah diatur oleh undang-undang perpajakan. Kesadaran perpajakan merupakan faktor lain yang tidak kalah pentingnya dalam mempengaruhi kepatuhan wajib pajak dalam memenuhi kewajiban perpajakannya. Kesadaran wajib pajak akan perpajakan adalah rasa timbul dari dalam diri wajib pajak atas kewajibannya membayar pajak dengan ikhlas tanpa adanya unsur paksaan.

Penelitian-penelitian terdahulu telah banyak membahas tentang pengaruh kepatuhan wajib pajak dan faktor-faktor yang mempengaruhinya. Seperti penelitian yang dilakukanMutia(2014) menyimpulkan bahwa sanksi perpajakan, kesadaran perpajakan, pelayanan fiskus dan tingkat pemahaman berpengaruh signifikan terhadap kepatuhan wajib pajak orang pribadi di KPP Pratama Padang. Penelitian lain Ananda et al.,(2015)yang dilakukan pada UMKM yang terdaftar sbagai wajib pajak di KPP Pratama Batu, menyimpulkan bahwa sosialisasi perpajakan memiliki pengaruh signifikan terhadap kepatuhan wajib pajak sebesar 0,252, tarif pajak memiliki pengaruh signifikan terhadap kepatuhan wajib pajak sebesar 0,413 , dan pemahaman perpajakan memiliki pengaruh signifikan terhadap kepatuhan wajib pajak sebesar 0,217.

Namun berbeda dengan hasil penelitian sebelumnya Burhan(2015)menyimpulkan bahwa sosialisasi perpajakan, pengetahuan perpajakan, dan persepsi wajib pajak tentang PP 46 tahun 2013 berpengaruh positif dan signifikan terhadap kepatuhan wajib pajak orang pribadi. Sedangkan persepsi wajib pajak tentang sanksi pajak tidak berpengaruh terhadap kepatuhan wajib pajak orang pribadi di Kabupaten Banjanegara.

Begitupun denganWarouw et al.,(2015), penelitian ini menjelaskan bahwa Secara parsial Sanksi Perpajakan memberikan pengaruh yang signifikan terhadap Kepatuhan Pelaporan SPT Tahunan Wajib Pajak Badan, tetapi Sosialisasi Perpajakan tidak memberikan pengaruh signifikan terhadap Kepatuhan Pelaporan SPT Tahunan Wajib Pajak Badan di KPP Pratama Manado dan KPP Pratama Bitung. Sedangkan, penelitian ini akan dilakukan pada KPP Pratama Jayapura untuk melihat kepatuhan pelaporan SPT Tahunan Wajib Pajak Orang Pribadi.

Penelitian ini memiliki rumusan masalah yaitu 1). Apakah sosialisasi perpajakan berpengaruh terhadap kesadaran perpajakan dalam melaporkan SPT Tahunan ?, 2). Apakah sosialisasi perpajakan berpengaruh terhadap kepatuhan wajib pajak orang pribadi dalam melaporkan SPT Tahunan ?, 3). Apakah tariff pajak berpengaruh terhadap kepatuhan wajib pajak orang pribadi dalam melaporkan SPT Tahunan ?, 4). Apakah sanksi perpajakan berpengaruh terhadap kepatuhan wajib pajak orang pribadi dlaam melaporkan SPT Tahunan ?, 5). Apakah kesadaran perpajakan berpengaruh terhadap kepatuhan wajib pajak orang pribadi dalam melaporkan SPT Tahunan ?, dan 6). Apakah sosialisasi perpajakan berpengaruh terhadap kepatuhan wajib pajak orang pribadi dalam melaporkan SPT Tahunan melalui kesadaran perpajakan?. Dengan tujuan penelitian: 1). Untuk menganalisis pengaruh sosialisasi perpajakan terhadap kesadaran perpajakan dalam melaporkan SPT Tahunan. 2). Untuk menganalisis pengaruh sosialisasi perpajakan terhadap kepatuhan wajib pajak orang pribadi dalam melaporkan SPT Tahunan. 3). Untuk menganalisis pengaruh tariff pajak terhadap kepatuhan wajib pajak orang pribadi dalam melaporkan SPT Tahunan. 4). Untuk menganalisis pengaruh sanksi perpajakan terhadap kepatuhan wajib pajak orang pribadi dalam melaporkan SPT Tahunan. 5). Untuk menganalisis pengaruh kesadaran perpajakan terhadap kepatuhan wajib pajak orang pribadi dalam 
melaporkan SPT Tahunan. Dan 6). Untuk menganalisis pengaruh sosialisasi perpajakan terhadap kepatuhan wajib pajak orang pribadi dalam melaporkan SPT Tahunan melalui kesadaran perpajakan.

\section{TINJAUAN PUSTAKA}

\subsection{Theory of Planed Behavior}

Dalam Theory of Planned Behavior (TPB) dijelaskan bahwa perilaku yang ditimbulkan oleh individu muncul karena adanya niat untuk berperilaku. Sedangkan munculnya niat untuk berperilaku ditentukan oleh tiga faktor Ajzen (2002) yang dikutip oleh Mustikasari (2007), yaitu:

\section{a. Behavioral Beliefs}

Behavioral beliefs merupakan keyakinan individu akan hasil dari suatu perilaku dan evaluasi atas hasil tersebut. Sebelum individu melakukan sesuatu, individu tersebut akan memiliki keyakinan mengenai hasil yang akan diperoleh dari perilakunya tersebut. Kemudian yang bersangkutan akan memutuskan bahwa akan melakukannya atau tidak melakukannya. Hal tersebut berkaitan dengan kesadaran wajib pajak. Wajib pajak yang sadar pajak, akan memiliki keyakinan mengenai pentingnya membayar pajak untuk membantu menyelenggarakan pembangunan negara.

\section{b. $\quad$ Normative Beliefs}

Normative beliefs yaitu keyakinan tentang harapan normatif orang lain dan motivasi untuk memenuhi harapan tersebut. Hal ini dapat dikaitkan dengan penyuluhan-penyuluhan pajak yang memberikan motivasi kepada wajib pajak agar taat pajak, akan membuat wajib pajak memiliki keyakinan atau memilih perilaku taat pajak.

\section{c. Control Beliefs}

Control beliefs merupakan keyakinan tentang keberadaan hal-hal yang mendukung atau menghambat perilaku yang akan ditampilkan dan persepsinya tentang seberapa kuat hal-hal yang mendukung dan menghambat perilakunya tersebut (perceived power). Sanksi pajak dan tarif pajak terkait dengan control beliefs. Sanksi pajak dibuat adalah untuk mendukung agar wajib pajak mematuhi peraturan perpajakan. Kepatuhan wajib pajak akan ditentukan berdasarkan persepsi wajib pajak tentang seberapa kuat sanksi pajak mampu mendukung perilaku wajib pajak untuk taat pajak. Pemberlakuan tarif pajak mempengruhi wajib pajak dalam membayar pajak, semakin adil tarif pajak yang ditetapkan maka akan mendukung perilaku wajib pajak untuk membayar pajak.

Penelitian tentang kepatuhan pajak telah banyak dilakukan. Penelitian sebelumnya yang menggunakan teori tersebut adalah penelitian Burhan(2015) mengenai Pengaruh Sosialisasi Perpajakan, Pengetahuan Perpajakan, Persepsi Wajib Pajak dan Implementasi PP Nomor 46 Tahun 2013 Terhadap Kepatuhan Wajib Pajak Orang Pribadi. Dikaitkan dengan penelitian ini, Theory of Planned Behavior relevan untuk menjelaskan perilaku patuh wajib pajak dalam memenuhi kewajibannya membayar pajak. Motivasi dari dalam diri wajib pajak dapat ditingkatkan dengan adanya sosialisasi perpajakan untuk menambah pengetahuan wajib pajak. Sanksi Pajak yang dikenakan juga dapat membuat wajib pajak enggan untuk melanggar peraturan perpajakan, sehingga dapat memaksimalkan kepatuhan wajib pajak dalam memenuhi kewajibannya membayar pajak.

\subsection{Teori Atribusi}

Pada dasarnya teori atribusi menyatakan bahwa bila individu-individu mengamati perilaku seseorang, kemudian mencoba menentukan apakah perilaku tersebut ditimbulkan secara internal atau eksternal. Perilaku yang disebabkan secara internal adalah perilaku yang diyakini dibawah kendali perilaku individu itu sendiri. Sedangkan perilaku eksternal adalah perilaku yang dipengaruhi dari luar, artinya individu akan berperilaku karena terpaksa dari situasi atau lingkungan. Penentuan faktor internal dan eksternal menurut Jatmiko(2006) tergantung pada tiga faktor : 


\section{Kekhususan (kesendirian atau Distinctiveness)}

Kekhususan artinya seseorang akan mempersepsikan perilaku individu lain secara berbeda-beda dalam situasi yang berlainan. Individu lain yang bertindak sebagai pengamat akan memberikan atribusi eksternal terhadap perilaku tersebut jika perilaku seseorang dianggap suatu hal yang tidak biasa. Sebaliknya, jika hal itu dianggap biasa, maka akan dinilai atribusi internal.

\section{Konsensus}

Konsensus artinya dalam situasi yang sama, seseorang mempunyai kesamaan pandangan dalam merespon perilaku. Apabila konsensusnya tinggi, maka termasuk atribusi eksternal. Sebaliknya, apabila konsensusnya rendah, maka termasuk atribusi internal.

\section{Konsistensi}

Konsistensi artinya jika seseorang dari waktu ke waktu menilai perilaku-perilaku orang lain dengan respon yang sama. Semakin konsistensi perilaku itu, orang akan menghubungkan hal tersebut dengan sebab-sebab internal, dan sebaliknya.

Teori atribusi mengelompokkan dua hal yang dapat memutarbalikkan arti dari atribusi. Pertama, kekeliruan atribusi mendasar yaitu kecenderungan untuk meremehkan pengaruh faktor-faktor eksternal daripada faktor-faktor internalnya. Kedua, prasangka layanan dari seseorang cenderung menghubungkan kesuksesan karena akibat faktor-faktor internal, sedangkan kegagalannya dihubungkan dengan faktor-faktor eksternal. Jatmiko(2006) melakukan penelitian perpajakan dengan hasil penelitian menyatakan bahwa sikap wajib pajak terhadap pelaksanaan sanksi denda, pelayanan fiskus, dan kesadaran perpajakan berpengaruh terhadap kepatuhan wajib pajak.

\subsection{Teori Pembelajaran Sosial}

Teori pembelajaran sosial mengatakan bahwa seseorang dapat belajar lewat pengamatan langsung atau pengalaman. Menurut, proses dalam pembelajaran sosial meliputi :

1. Proses Perhatian

2. Proses Penahanan

3. Proses reproduksi motorik

4. Proses penguatan

Proses perhatian yaitu orang hanya akan belajar dari seseorang atau model, jika mereka telah mengenal dan menaruh perhatian pada seseorang atau model tersebut. Proses penahanan adalah proses mengingat tindakan suatu model setelah model tidak lagi tersedia. Proses reproduksi motorik adalah proses mengubah pengamatan menjadi perbuatan. Proses penguatan adalah proses yang mana individu-individu disediakan rangsangan positif atau ganjaran supaya berperilaku sesuai dengan model (Jatmiko, 2006).

Jatmiko(2006) menjelaskan bahwa teori pembelajaran sosial ini relevan untuk menjelaskan perilaku wajib pajak dalam memenuhi kewajiban perpajakannya. Seseorang akan taat membayar pajak tepat pada waktunya, jika lewat pengamatan dan pengalaman langsungnya, hasil pungutan pajak itu telah memberikan kontribusi nyata pada bangunan di wilayahnya. Terkait dengan proses penguatan, dimana individu-individu disediakan rangsangan positif atau ganjaran supaya berperilaku sesuai dengan model, tampaknya cukup relevan apabila dihubungkan dengan sanksi pajak terhadap kepatuhan pajak.

\subsection{Sosialisasi Perpajakan}

Sosialisasi adalah suatu konsep umum yang dimaknakan sebagai proses dimana kita belajar melalui interaksi dengan orang lain, tentang cara berfikir, merasakan dan bertindak dimana kesemuanya itu merupakan hal-hal yang sangat penting dalam menghasilkan partisipasi social yang efektif (Septiani, Sirajuddin, \& Sugara, 2013). Menurut Savitri \& Musfialdy(2016) sosialisasi 
perpajakan adalah upaya oleh Direktorat Jenderal Pajak untuk memberikan informasi, pemahaman dan bimbingan kepada publik terutama wajib pajak tentang peraturan Undang-undang perpajakan.

Ditjen Pajak memberikan beberapa point terkait indikator sosialisasi dimana kegiatan tersebut diharapkan dapat memberikan kesadaran dan rasa peduli terhadap pajak yang dimodifikasi dari pengembangan program pelayanan perpajakan (Wirenungan, 2013) : a). Penyuluhan, b). Berdiskusi langsung dengan Wajib Pajak dan tokoh masyarakat, c). Informasi langsung dari petugas (fiskus) ke Wajib Pajak, d). Pemasangan billboard, dan e). Website Ditjen Pajak.

\subsection{Tarif Pajak}

Tarif pajak adalah suatu penetapan atau persentase berdasarkan undang-undang yang dapat digunakan untuk menghitung dan/atau menentukan jumlah pajak yang harus dibayar, disetor dan/atau dipungut oleh wajib pajak. Pada umumnya tarif pajak di Indonesia ditentukan berdasarkan persentase (\%), tapi ada juga tarif pajak yang hanya berupa nominal saja (Tawas et al., 2016). Ada beberapa jenis tarif pajak yang digunakan negara sebagai acuan untuk menghitung tarif pajak, yaitu : a). Tarif Pajak Progresif, b). Taris Pajak Proporsional, c). Tarif pajak Degresif, dan d). Tarif Pajak Tetap.

\subsection{Sanksi Perpajakan}

Sanksi adalah suatu tindakan berupa hukuman yang diberikan kepada orang yang melanggar peraturan. Peraturan atau Undang-undang merupakan rambu-rambu bagi seseorang untuk melakukan sesuatu mengenai apa yang harus dilakukan dan apa yang seharusnya tidak dilakukan. Supaya peraturan dan Undang-undang tidak dilanggar maka diperlukan suatu sanksi. Sanksi pajak merupakan jaminan bahwa ketentuan peraturan perundang-undangan perpajakan (norma perpajakan) akan dituruti/ditaati/dipatuhi, dengan kata lain sanksi perpajakan merupakan alat pencegah agar wajib pajak tidak melanggar norma perpajakan (Arum, 2012).

Sanksi perpajakan dikenal dua macam dalam undang-undang perpajakan yang dikutip oleh Rohmawati \& Rasmini(2012), yaitu Sanksi Administrasi dan Sanksi Pidana. Ancaman terhadap pelanggaran suatu norma perpajakan ada yang diancam dengan sanksi administrasi saja, ada yang diancam dengan sanksi pidana saja, dan ada pula yang diancam dengan sanksi administrasi dan sanksi pidana.

\subsection{Kesadaran Perpajakan}

Kesadaran merupakan unsur dalam diri manusia untuk memahami realitas dan bagaimana mereka bertindak atau bersikap terhadap realitas. Menurut Andreas \& Savitri(2015) secara umum kesadaran wajib pajak untuk membayar pajak akan menciptakan moralitas perpajakan. Jatmiko(2006)menguraikan beberapa bentuk kesadaran membayar pajak yang mendorong wajib pajak untuk membayar pajak.

Pertama, kesadaran bahwa pajak merupakan bentuk partisipasi dalam menunjang pembangunan negara. Dengan menyadari hal ini, wajib pajak mau membayar pajak karena merasa tidak dirugikan dari pemungutan pajak yang dilakukan.

Kedua, kesadaran bahwa penundaan pembayaran pajak dan pengurangan beban pajak sangat merugikan negara. Wajib pajak mau membayar pajak karena memahami bahwa penundaan pembayaran pajak dan pengurangan beban pajak berdampak pada kurangnya sumber daya finansial yang dapat mengakibatkan terhambatnya pembangunan negara.

Ketiga, kesadaran bahwa pajak ditetapkan dengan Undang-undang dan dapat dipaksakan. Wajib pajak akan membayar karena pembayaran pajak disadari memiliki landasan hukum yang kuat dan merupakan kewajiban mutlak setiap warga negara. 


\subsection{Kepatuhan Wajib Pajak}

Menurut Saad(2014) kepatuhan pajak sebagai pengisian semua pengembalian pajak yang diisyaratkan pada waktu yang tepat dan yang mengembalikan laporan kewajiban pajak secara akurat sesuai dengan Undang-undang pajak yang berlaku pada saat pengembalian diajukan.

Ada dua macam kepatuhan, yaitu kepatuhan formal dan kepatuhan material. Kepatuhan formal adalah suatu keadaan di mana wajib pajak memenuhi kewajiban secara formal sesuai dengan ketentuan dalam undang-undang perpajakan. Sedangkan kepatuhan material adalah suatu keadaan dimana wajib pajak memenuhi semua ketentuan material perpajakan, yakni sesuai dengan isi dan jiwa undang-undang perpajakan. Kepatuhan material dapat juga meliputi kepatuhan formal (Wirenungan, 2013).

\subsection{Penelitian Terdahulu dan Pengembangan Hipotesis}

\subsubsection{Pengaruh Sosialisasi Perpajakan Terhadap Kesadaran Perpajakan Dalam Melaporkan SPT Tahunan}

Hasil Penelitian Astuti(2017) menyatakan bahwa terdapat pengaruh sosialisasi terhadap kesadaran wajib pajak. Sosialisasi perpajakan adalah salah satu bentuk upaya oleh Dirjen Pajak yang diharapkan untuk meningkatkan pengetahuan dan kesadaran kepada masyarakat terutama wajib pajak akan pentingnya pajak bagi pembangunan negara. Hal ini didukung oleh penelitian Wulandari (2015) dan juga Yuwono(2015) yang menyatakan sosialisasi perpajakan berpengaruh signifikan terhadap kesadaran perpajakan. Apabila sosialisasi dilakukan dengan baik dan sering dilakukan, maka kesadaran wajib pajak akan semakin baik.

Menurut Penelitian yang dilakukan oleh Puspita(2016) menyatakan bahwa terdapat pengaruh antara sosialisasi terhadap kesadaran wajib pajak. Apabila sosialisasi semakin sering dan menggunakan media yang efektif, maka dapat meningkatkan kesadaran wajib pajak akan hak dan kewajiban perpajakannya. Berdasarkan hal tersebut maka dirumuskan hipotesis sebagai berikut:

H1 : Sosialisasi perpajakan berpengaruh terhadap kesadaran perpajakan dalam melaporkan SPT

Tahunan

\subsubsection{Pengaruh Sosialisasi Perpajakan Terhadap Kepatuhan Wajib pajak Orang Pribadi Dalam Melaporkan SPT Tahunan}

Sosialisasi perpajakan, diharapkan dapat meningkatkan kepatuhan wajib pajak sehingga jumlah penerimaan pajak dapat bertambah sesuai target. Kepatuhan wajib pajak dapat dicapai dengan adanya sosialisasi perpajakan yang dilakukan secara intensif dan efektif oleh Direktorat Jenderal Pajak atau dalam hal ini adalah Kantor Pelayanan Pajak.

Hasil penelitian Burhan(2015) mengemukakan bahwa sosialisasi perpajakan berpengaruh positif dan signifikan terhadap kepatuhan wajib pajak. Ketika masyarakat khususnya wajib pajak orang pribadi mengetahui dan memahami peraturan perpajakan yang berlaku maka semakin patuh wajib pajak tersebut untuk memenuhi kewajiban perpajakannya. Hal tersebut di dukung oleh Widiastuti, Astuti, \&Susilo(2013), Dharma \& Suardana(2014)Ananda et al.,(2015), Andriani, Y., Herianti (2015), yang menyatakan bahwa sosialisasi perpajakan berpengaruh signifikan terhadap kepatuhan wajib pajak.

Berbeda dengan penelitian Tawas et al.,(2016) menyatakan secara parsial sosialisasi perpajakan tidak memberikan pengaruh signifikan terhadap kepatuhan wajib pajak orang pribadi. Hal ini didukung olehWarouw et al.,(2015) dan Veronica(2015) yang menyatakan secara parsial sosialisasi perpajakan tidak memberikan pengaruh signifikan terhadap kepatuhan wajib pajak. Dan 
penelitian sebelumnya Wirenungan(2013) menyatakan sosialisasi perpajakan tidak berpengaruh terhadap wajib pajak orang pribadi. Berdasarkan hal tersebut maka dirumuskan hipotesis sebagai berikut:

H2 : Sosialisasi perpajakan berpengaruh terhadap kepatuhan Wajib Pajak Orang Pribadi dalam melaporkan SPT Tahunan

\subsubsection{Pengaruh Tarif Pajak Terhadap Kepatuhan Wajib Pajak Orang Pribadi Dalam Melaporkan SPT Tahunan}

Hasil penelitian Ananda et al.,(2015) menyatakan bahwa tarif pajak mempunyai pengaruh signifikan terhadap kepatuhan wajib pajak. Hal ini didukung oleh penelitian Tawas et al.,(2016) dan Kristanty, Khairani, \& Fajriana(2014) bahwa tarif pajak memberikan pengaruh signifikan terhadap kepatuhan wajib pajak. Dalam pemungutan pajak harus ditetapkan terlebih dahulu jenis tarif yang dipergunakan, karena tarif ini berhubungan erat dengan fungsi pajak, yaitu fungsi butget dan fungsi mengatur.Tarif pajak yang besarnya harus dicantumkan dalam undang-undang pajak merupakan salah satu unsur yang menentukan rasa keadilan dalam pemungutan pajak. Penentuan besarnya suatu tarif adalah hal yang krusial dimana kesalahan persepsi dalam penentuannya dapat merugikan berbagai pihak termasuk Negara. Namun hal ini berbeda dengan penelitian Suhendri(2015)yang menyatakan tarif pajak tidak memberikan pengaruh signifikan terhadap kepatuhan wajib pajak. Berdasarkan hal tersebut maka dirumuskan hipotesis sebagai berikut:

H3 : Tarif pajak berpengaruh terhadap kepatuhan Wajib Pajak Orang Pribadi dalam melaporkan SPT Tahunan

\subsubsection{Pengaruh Sanksi Perpajakan Terhadap Kepatuhan Wajib Pajak Orang Pribadi Dalam Melaporkan SPT Tahunan}

Hasil penelitian Tene et al.,(2017) menyatakan bahwa sanksi perpajakan berpengaruh terhadap kepatuhan wajib pajak. Hal ini didukung oleh penelitian Tawas et al.,(2016), Warouw etal.,(2015), Mutia (2014), Suhendri(2015), Veronica(2015), Tologana (2015)yang menyatakan sanksi perpajakan berpengaruh signifikan terhadap kepatuhan wajib pajak. Sanksi diterapkan supaya wajib pajak memenuhi kewajibannya dalam membayar pajak. Jika sanksi yang dikenakan berat maka wajib pajak akan patuh . Penerapan sanksi perpajakan tergolong sanksi administrasi dan sanksi pidana, namun penerapan sanksi harus konsistensi dan berlaku terhadap semua wajib pajak yang tidak memenuhi kewajiban perpajakannya.

Penelitian sebelumnya Arum(2012), Rohmawati \& Rasmini(2012), Jatmiko(2006), Tiraada(2013) menyatakan sanksi perpajakan berpengaruh positif signifikan terhadap kepatuhan wajib pajak. Berbeda dengan penelitian Wirenungan(2013) yang menyatakan sanksi perpajakan tidak berpengaruh terhadap kepatuhan wajib pajak. Hal ini didukung oleh (Setiyoningrum et al., n.d.) yang menyatakan sanksi perpajakan tidak berpengaruh terhadap kepatuhan wajib pajak. Berdasarkan hal tersebut maka dirumuskan hipotesis sebagai berikut :

H4 : Sanksi perpajakan berpengaruh terhadap kepatuhan Wajib Pajak Orang Pribadi dalam melaporkan SPT Tahunan

\subsubsection{Pengaruh Kesadaran Perpajakan Terhadap Kepatuhan Wajib Pajak Orang Pribadi Dalam Melaporkan SPT Tahunan}

Hasil penelitian Mutia(2014) menyatakan bahwa kesadaran perpajakan berpengaruh signifikan terhadap kepatuhan wajib pajak. Hal ini di dukung oleh Dharma \& Suardana(2014), Tiraada(2013), Tene et al.,(2017), Mahmud, Muhammad, \& Syukriy(2017), Setyowati(2017) bahwakesadaran perpajakan berpengaruh positif signifikan terhadap kepatuhan wajib pajak. Kesadaran wajib pajak 
adalah suatu kondisi dimana wajib pajak mengetahui, memahami dan melaksanakan ketentuan perpajakan dengan benar dan sukarela. Semakin tinggi tingkat kesadaran wajib pajak maka pamahaman dan pelaksanaan kewajiban perpajakan semakin baik sehingga dapat meningkatkan kepatuhan. Dalam penelitian sebelumnya Arum(2012) dan Jatmiko(2006) menyatakan bahwa kesadaran perpajakan berpengaruh signifikan terhadap kepatuhan wajib pajak. Berdasarkan hal tersebut maka dirumuskan hipotesis sebagai berikut :

H5 : Kesadaran perpajakan berpengaruh terhadap kepatuhan Wajib Pajak Orang Pribadi dalam melaporkan SPT Tahunan.

\subsubsection{Pengaruh Sosialisasi Perpajakan Terhadap Kepatuhan Wajib Pajak Orang Pribadi Dalam Melaporkan SPT Tahunan Melalui Kesadaran Perpajakan}

Hasil Penelitian Puspita(2016) menyatakan bahwa sosialisasi perpajakan berpengaruh terhadap kepatuhan melalui kesadaran. Sosialisasi dapat lebih meningkatkan kepatuhan wajib pajak apabila wajib pajak tersebut menyadari mengenai hak dan kewajiban serta peraturan dan tata cara perpajakan yang berlaku. Hal ini di dukung oleh penelitian Astuti(2017) yang menyatakan adanya pengaruh sosialisasi terhadap kepatuhan pajak melalui kesadaran sebagai variabel intervening.

Berbeda dengan penelitian (Wulandari, 2015) yang menyatakan kesadaran wajib pajak tidak bisa dijadikan variabel intervening sosialisasi perpajakan terhadap kepatuhan wajib pajak. Berdasarkan hal tersebut maka dirumuskan hipotesis sebagai berikut :

H6 : Sosialisasi perpajakan berpengaruh terhadap kepatuhan Wajib Pajak Orang Pribadi dalam melaporkan SPT Tahunan melalui kesadaran perpajakan.

\subsection{Model Penelitian}

Model penelitian ini adalah tentang pengaruh sosialisasi perpajakan, tarif pajak, sanksi perpajakan, dan kesadaran perpajakan terhadap kepatuhan pelaporan SPT tahunan wajib pajak orang pribadi. Gambar 1 menyajikan model penelitian untuk pengembangan hipotesis pada penelitian ini:

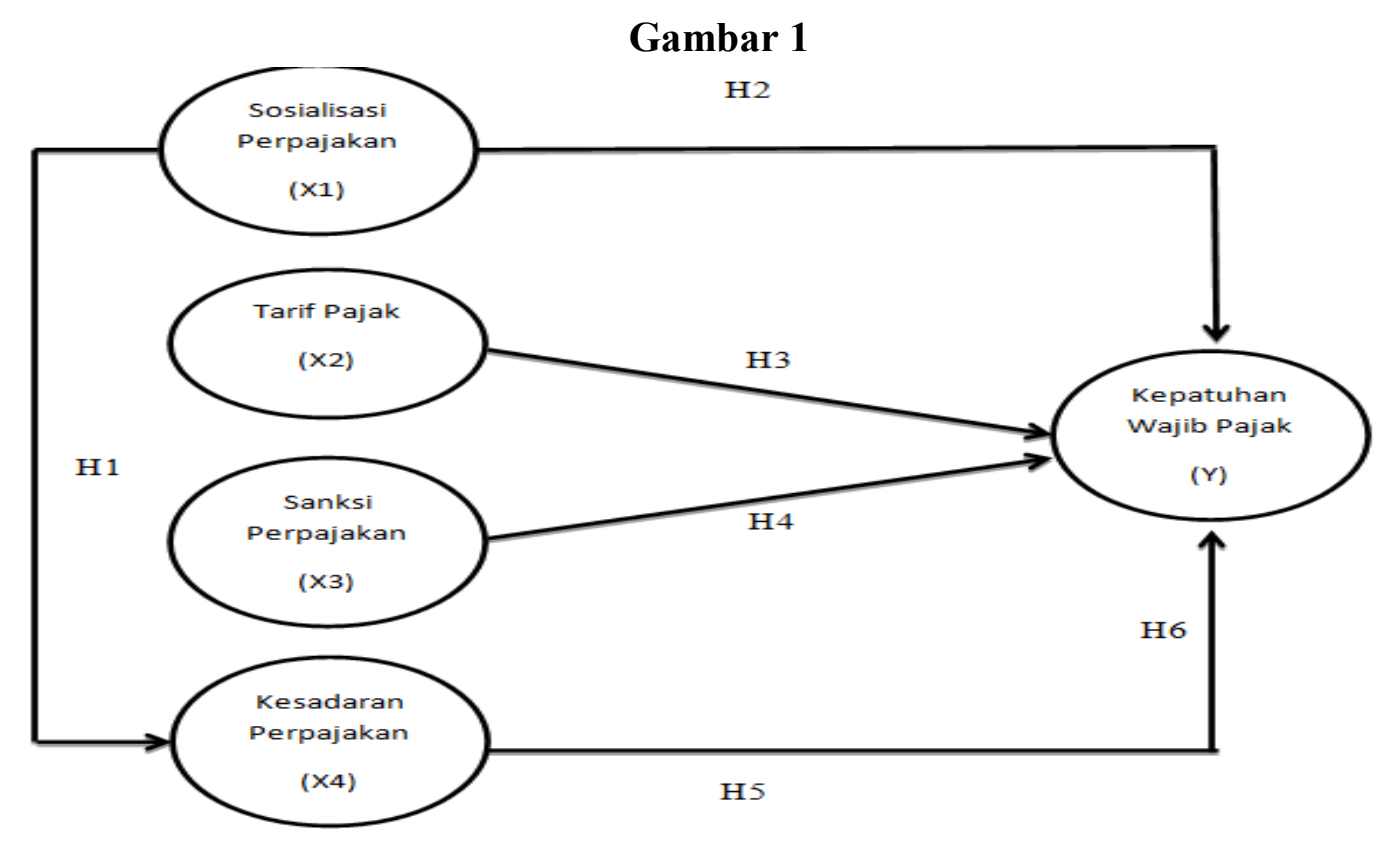

Sumber: Penulis (2018) 


\section{METODE PENELITIAN}

\subsection{Jenis Penelitian}

Jenis penelitian ini bersifat kausal komparatif (causal comparative reaserch) yang merupakan tipe penelitian dengan karakteristik masalah berupa hubungan sebab akibat antara dua variabel atau lebih.

\subsection{Populasi dan Sampel Penelitian}

Populasi dalam penelitian ini adalah Wajib Pajak Orang Pribadi (WPOP) yang terdaftar di KPP Pratama Jayapura. Wajib pajak terdaftar ditandai dengan kepemilikan Nomor Pajak Wajib Pajak (NPWP).

Sampel dalam penelitian ini adalah Wajib Pajak Orang Pribadi (WPOP) yang melaporkan Surat Pemberitahuan Tahunan (SPT). Teknik pengambilan sampel yang digunakan adalah Convienance Sampling atau penyampelan dengan berdasarkan kemudahan, yaitu wajib pajak orang pribadi yang pada hari tersebut melaporkan SPT dan melakukan pekerjaan perpajakan di KPP Pratama Jayapura.

\subsection{Jenis Data dan Sumber Data}

Data yang digunakan dalam penelitian ini adalah data primer, dimana data primer merupakan data yang berasal langsung dari sumber data yang dikumpulkan secara khusus dan berhubungan dengan permasalahan yang diteliti. Sumber data primer tersebut diperoleh langsung oleh wajib pajak yang berada di kota Jayapura dan terdaftar di Kantor Pelayanan Pajak Pratama Jayapura. Data tersebut merupakan kuisioner yang telah diisi oleh Wajib Pajak yang menjadi responden terpilih dalam penelitian ini.

\subsection{Definisi Operasional}

1. Sosialisasi perpajakan adalah upaya yang dilakukan untuk menambah pemahaman atau pengetahuan kepada masyarakat terutama wajib pajak agar mengetahui tata cara pembayaran perpajakan dengan baik. Kuesioner yang digunakan mengacu pada kuesioner (Tawas et al., 2016), variabel ini terdiri dari 5 item pertanyaan dan diukur dengan menggunakan skala Likert 1-5.

2. Tarif pajak adalah suatu penetapan atau persentase berdasarkan peraturan perundang-undangan perpajakan yang dapat digunakan untuk menghitung dan atau menentukan jumlah pajak yang harus dibayar, disetor dan atau dipungut oleh wajib pajak. Kuesioner yang digunakan mengacu pada kuesioner (Tawas et al., 2016), variabel ini terdiri dari 4 item pertanyaan dan diukur dengan menggunakan skala Likert 1-5.

3. Sanksi perpajakan merupakan jaminan bahwa peraturan perundang-undangan perpajakan dipatuhi. Dengan kata lain sanksi perpajakan merupakan alat pencegah agar wajib pajak tidak melanggar norma perpajakan. Kuesioner yang digunakan mengacu pada kuesioner (Tawas et al., 2016), variabel ini terdiri dari 5 item pertanyaan dan diukur dengan menggunakan skala Likert 1-5.

4. Kesadaran adalah suatu kondisi dimana wajib pajak mengetahui, mengakui, menghargai, dan menaati ketentuan perpajakan yang berlaku serta memiliki kesanggupan dan kemauan untuk memenuhi kewajiban pajaknya. Kuesioner yang digunakan mengacu pada kuesioner (Mutia, 2014), variabel ini terdiri dari 5 item pertanyaan dan diukur dengan menggunakan skala Likert 1-5.

5. Kepatuhan berarti tunduk atau patuh pada ajaran dalam perpajakan merupakan ketaatan, tunduk, dan patuh, serta melaksanakan ketentuan perpajakan sehingga, wajib pajak yang patuh adalah wajib pajak yang taat dan mematuhi serta melaksanakan kewajiban perpajakan sesuai ketentuan peraturan undang-undang perpajakan. Dimana mematuhi serta melaksanakan kewajiban perpajakan yang dimaksud diantaranya yaitu mengisi formulir dengan benar, menghitung pajak terhutangnya dengan benar, membayar tepat waktu, melaporkan informasi ketika petugas membutuhkan informasi lebih, 
dan mematuhi kebijakan tersebut. Kuesioner yang digunakan mengacu pada kuesioner (Tawas et al., 2016), variabel ini terdiri dari 7 item pertanyaan dan diukur dengan menggunakan skala Likert 1-5.

\subsection{Metode Analisis Data}

Penelitian ini menggunakan software SmartPLS 3.0 PLS (Partial Least Squares). Menurut (Ghozali, 2014) dalam menganalisis data menggunakan PLS ada beberapa hal yang dilakukan yaituuji outer model yang terdiri atasconvergent validity.Ukuran refleksi individual dikatakan tinggi jika berkolerasi $\geq 0,70$ dengan konstruk yang ingin diukur. Namun demikian untuk penelitian tahap awal dari pengembangan skala pengukuran nilai loading 0,50 sampai 0,60 dianggap cukup.Uji discriminant validity, jika korelasi konstruk dengan item pengukuran lebih besar daripada ukuran konstruk lainnya, maka hal tersebut menunjukkan bahwa konstruk laten memprediksi ukuran pada blok mereka lebih baik daripada ukuran pada blok lainnya. Metode lain untuk menilai discriminant validity adalah membandingkan nilai AVE, direkomendasikan nilai AVE harus lebih besar 0,50. Uji composite reliability, konstruk dikatakan reliable jika nilai composite reliability maupun cronbach's alpha di atas 0,70 .

Selain uji outer model, terdapat uji inner model yang dievaluasi dengan menggunakan koefisien determinasi $\left(\mathrm{R}^{2}\right)$ untuk setiap variabel laten dependen.Dalam menilai model dengan PLS dimulai dengan melihat $\mathrm{R}$-square untuk setiap variabel laten dependen. Disamping melihat nilai $\mathrm{R}^{2}$, juga dievaluasi dengan melihat $\mathrm{Q}^{2}$ predictive relevance untuk model konstruk. Nilai $\mathrm{Q}^{2}>0$ (nol) menunjukkan bahwa model mempunyai nilai prediktive relevance, sedangkan nilai $<0$ (nol) menunjukkan bahwa model kurang memiliki predictive relevance.

\section{HASIL PENELITIAN DAN PEMBAHASAN \\ 4.1 Gambaran Umum Responden}

Kuesioner disebarkan dengan cara mengantar langsung kepada wajib pajak orang pribadi yang pada hari tersebut melaporkan SPT dan melakukan pekerjaan perpajakan di KPP Pratama Jayapura. Penelitian ini dilakukan pada tanggal 9 Mei 2018 sampai dengan 08 Juni 2018. Jadi, kurang lebih penelitian ini berlangsung selama 1 (satu) bulan. Kuesioner yang telah disebarkan berjumlah 110 kuesioner dimana kuesioner yang tidak lengkap sejumlah 10 kuesioner dan terdapat 100 kuesioner yang layak diolah, sehingga tingkat pengembalian sebesar $(90,91 \%)$.

\subsection{Hasil Uji PLS Algorithm}

\section{Gambar 2}

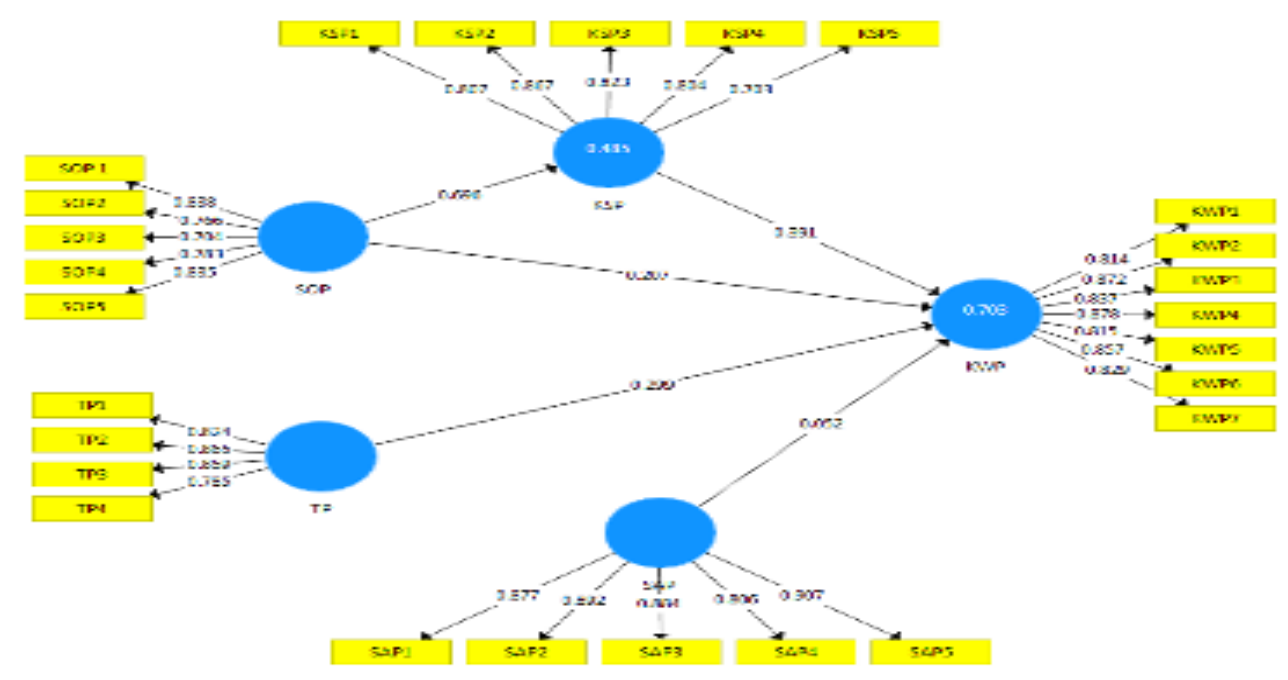

Sumber: Data Olah PLS (2018) 
Keterangan :

SOP : Sosialisasi Perpajakan KSP : Kesadaran Perpajakan

TP : Tarif Pajak

KWP : Kepatuhan Wajib Pajak

SAP : Sanksi Perpajakan

Indikator-indikator konstruk yang memenuhi nilai convergent validitydengan faktor loading> 0,5.Selain itu, hasil uji Average Variance Extracted (AVE) menunjukkan nilai AVE seluruh variabel lebih besar dari 0,5. Uji composite reliability seluruh variabel dan uji cronbach alpha telah memenuhi nilai loading-nya yaitu di atas 0,7 .Hal ini menyatakan bahwa seluruh variabel dapat dikatakan valid dan reliable.

Selain itu, dilakukan juga uji inner model dengan melihat nilai R-Square sebagai berikut:

\begin{tabular}{|l|c|}
\hline & R Square \\
\hline KSP & 0,485 \\
\hline KWP & 0,703 \\
\hline
\end{tabular}

Berdasarkan tabel di atas, koefisien determinasi r square menunjukkan bahwa variabel kesadaran perpajakan mampu dijelaskan oleh sosialisasi perpajakan sebesar 48,5\%, sisanya dijelaskan oleh faktor lain di luar model sebesar 51,5\%. Kepatuhan wajib pajak mampu dijelaskan oleh sosialisasi perpajakan, tarif pajak, sanksi perpajakan dan kesadaran perpajakan sebesar 70,3\%, sisanya dijelaskan oleh faktor lain di luar model sebesar 29,7\%.

Disamping melihat nilai R-square, suatu model dianggap mempunyai nilai predictive yang relevan jika nilai Q-square lebih besar dari $0(>0)$. Nilai predictive relevance diperoleh dengan rumus sebagai berikut:

$\mathrm{Q}^{2}=1-\left(1-\mathrm{R}_{1}^{2}\right)\left(1-\mathrm{R}_{2}^{2}\right)$

$\mathrm{Q}^{2}=1-\left(1-0,5^{2}\right)\left(1-0,7^{2}\right)$

$\mathrm{Q}^{2}=1-(1-0,25)(1-0,49)$

$\mathrm{Q}^{2}=1-(0,75)(0,51)$

$\mathrm{Q}^{2}=0,62$

\subsection{Hasil Pengujian Hipotesis}

Hasil pengujian hipotesis didapatkan dari pengujian Bootstrapping sebagai berikut:

\section{Gambar 3}

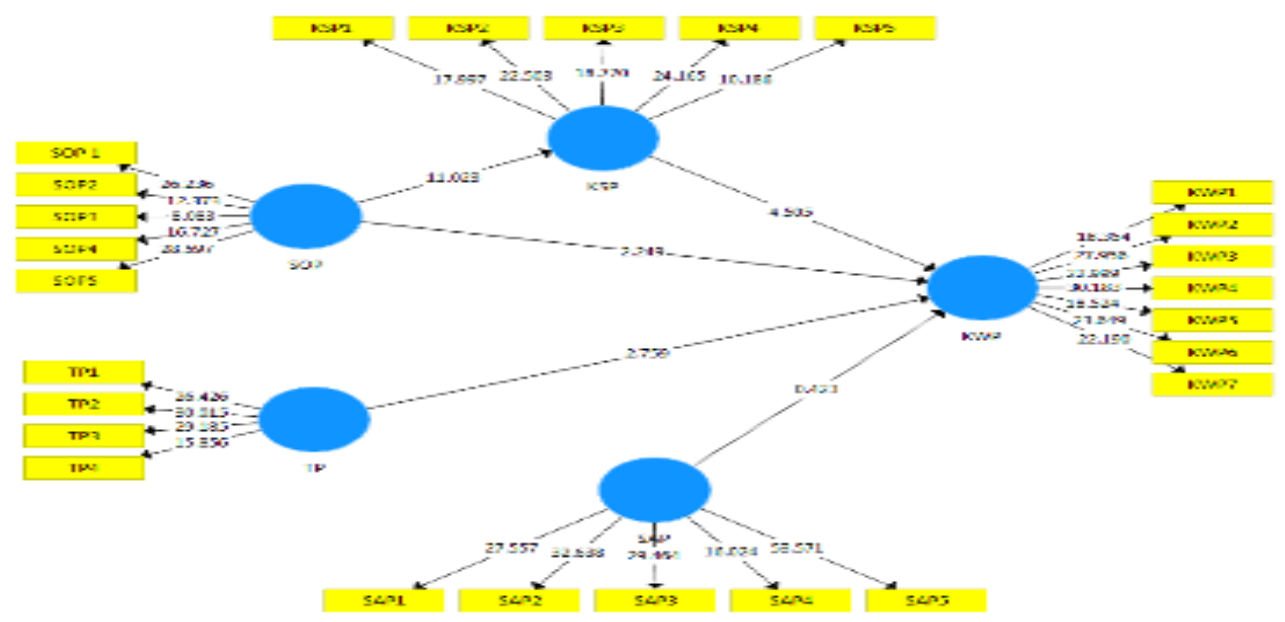

Sumber: Data Olah PLS (2018) 


\section{Tabel 1}

Hasil Pengujian Bootstrapping

\begin{tabular}{|l|c|c|c|c|c|}
\hline & $\begin{array}{c}\text { Original } \\
\text { Sample } \\
(\mathbf{O})\end{array}$ & $\begin{array}{c}\text { Sample } \\
\text { Mean } \\
(\mathbf{M})\end{array}$ & $\begin{array}{c}\text { Standard } \\
\text { Deviation } \\
\text { (STDEV) }\end{array}$ & T Statistics & P Values \\
\hline SOP -> KSP & 0,696 & 0,698 & 0,063 & 11,023 & 0,000 \\
\hline SOP -> KWP & 0,207 & 0,204 & 0,092 & 2,249 & 0,025 \\
\hline TP -> KWP & 0,299 & 0,318 & 0,109 & 2,759 & 0,006 \\
\hline SAP -> KWP & 0,052 & 0,041 & 0,123 & 0,423 & 0,673 \\
\hline KSP -> KWP & 0,391 & 0,387 & 0,087 & 4,505 & 0,000 \\
\hline
\end{tabular}

Sumber: Data Olah PLS (2018)

\subsection{Pembahasan}

\subsubsection{Pengaruh Sosialisasi Perpajakan Terhadap Kesadaran Perpajakan}

Berdasarkan hasil pengujian di atas, dapat diketahui bahwa variabel sosialisasi perpajakan berpengaruh signifikan dan berhubungan positif terhadap kesadaran perpajakan di KPP Pratama Jayapura. Hal ini menjelaskan bahwa sosialisasi sangat penting dilakukan, sehingga apabila sosialisasi yang dilakukan oleh KPP Pratama Jayapura sering dilakukan secara langsung maupun menggunakan media yang efektif maka dapat meningkatkan kesadaran perpajakan akan hak dan kewajiban perpajakannya. Hasil penelitian ini sejalan dengan Yuwono(2015) yang menemukan bahwa apabila sosialisasi dilakukan dengan baik dan sering dilakukan, maka kesadaran perpajakan akan semakin baik, namun sebaliknya apabila sosialisasi dilaksanakan tidak tepat dan tidak teratur, maka kesadaran perpajakan akan buruk. Begitu juga dengan hasil penelitian yang dilakukan oleh Wulandari(2015) yang menemukan bahwa kesadaran perpajakan akan terbentuk apabila masingmasing wajib pajak telah mengikuti sosialisasi perpajakan dan memahami isi dari sosialisasi yang dilakukan oleh kantor pelayanan pajak yang dapat meningkatkan pengetahuan wajib pajak serta kesadaran wajib pajak tentang kewajiban seorang wajib pajak.

\subsubsection{Pengaruh Sosialisasi Perpajakan Terhadap Kepatuhan Wajib Pajak Orang Pribadi Dalam Melaporkan SPT Tahunan}

Berdasarkan hasil pengujian di atas, dapat diketahui bahwa sosialisasi perpajakan berpengaruh signifikan dan berhubungan positif terhadap kepatuhan wajib pajak orang pribadi dalam melaporkan SPT tahunan di KPP Pratama Jayapura. Hal ini menjelaskan bahwa sosialisasi perpajakan sangat diperlukan oleh wajib pajak untuk meningkatkan kepatuhan wajib pajak. Sosialisasi perpajakan dapat merubah cara berpikir seseorang dari sebelumnya tidak patuh menjadi patuh dalam membayar kewajiban perpajakannya. Artinya, semakin sering sosialisasi yang dilaksanakan oleh KPP Pratama Jayapura maka akan semakin tinggi kepatuhan wajib pajak dalam membayar kewajiban perpajakannya.. Hasil Peneltian ini sejalan dengan Puspita(2016) yang menemukan bahwa semakin tinggi tingkat intensitas sosialisasi yang dilakukan, maka akan semakin tinggi pula tingkat kepatuhan wajib pajak. Karena dengan adanya sosialisasi, wajib pajak akan lebih mengetahui, memahami dan menyadari mengenai peraturan dan tata cara perpajakan, yang membuat wajib pajak dapat melaksanakan kewajiban perpajakannya dengan patuh. Dengan demikian hasil penelitian ini juga sejalan dengan Burhan(2015), Widiastuti et al., (2013), dan Ananda et al., (2015), yang menyatakan bila sosialisasi semakin sering dilaksanakan maka akan diikuti dengan peningkatan kepatuhan wajib pajak. 


\subsubsection{Pengaruh Tarif Pajak Terhadap Kepatuhan Wajib Pajak Orang Pribadi Dalam Melaporkan SPT Tahunan}

Berdasarkan hasil pengujian di atas, dapat diketahui bahwa tarif pajak berpengaruh signifikan dan berhubungan positif terhadap kepatuhan wajib pajakorang pribadi dalam melaporkan SPT tahunan di KPP Pratama Jayapura. Hal ini menjelaskan bahwa pemberlakuan tarif pajak mempengaruhi wajib pajak dalam membayar pajaknya. Pembebanan tarif pajak yang rendah membuat masyarakat tidak terlalu keberatan untuk memenuhi kewajibannya. Dalam pengertian lain, jika pembebanan tarif pajak yang tinggi sedangkan penghasilan wajib pajak rendah atau pembenanan tarif pajak yang rendah sedangkan penghasilan wajib pajak tinggi maka akan membuat tingkat kepatuhan wajib pajak menurun. Sehingga dapat dipahami semakin adil tarif pajak yang ditetapkan maka semakin tinggi tingkat kepatuhan wajib pajak dalam membayar pajaknya. Hal ini sejalan dengan Ananda et al., (2015) yang menyatakan bahwa tarif pajak mempengaruhi kepatuhan wajib pajak. Tarif pajak yang rendah akan meningkatkan utility wajib pajak sehingga memberikan inisiatif dalam melaporkan penghasilan kepada administrasi pajak.

\subsection{Pengaruh Sanksi Perpajakan Terhadap Kepatuhan Wajib Pajak Orang Pribadi Dalam Melaporkan SPT Tahunan}

Berdasarkan hasil pengujian di atas, dapat diketahui bahwa sanksi perpajakan tidak berpengaruh signifikan dan berhubungan positif terhadap kepatuhan wajib pajak orang pribadi dalam melaporkan SPT tahunan di KPP Pratama Jayapura. Hal ini menjelaskan bahwa masih banyak yang tidak patuh membayar kewajibannya tepat pada waktunya, karena wajib pajak menganggap tidak begitu memberatkan apabila terlambat membayar pajak sanksi administrasi yang ditetapkan sebesar $2 \%$ kepada wajib pajak orang pribadi. Hal ini sejalan dengan penelitian yang dilakukan oleh Wirenungan(2013) dan (Setiyoningrum et al., n.d.) yang menemukan bahwa sanksi perpajakan tidak memiliki hubungan yang signifikan dengan kepatuhan wajib pajak. Hal ini dapat disebabkan karena masih kurangnya kesadaran wajib pajak akan pentingnya pajak untuk pembangunan kota, yang selanjutnya mempengaruhi kepatuhan pajak orang pribadi.

\subsection{Pengaruh Kesadaran Perpajakan Terhadap Kepatuhan Wajib Pajak Orang Pribadi Dalam Melaporkan SPT Tahunan}

Berdasarkan hasil pengujian di atas, dapat diketahui bahwa kesadaran perpajakan berpengaruh signifikan dan berhubungan positif terhadap kepatuhan wajib pajak orang pribadi dalam melaporkan SPT tahunan di KPP Pratama Jayapura. Hal ini menjelaskan bahwa jika kesadaran meningkat maka kepatuhan wajib pajak akan meningkat. Sikap kesadaran yang tinggi mengenai pemahaman akan manfaat dan pentingnya pajak bagi kesejahteraan masyarakat dan dalam memajukan pembangunan daerah maupun pembangunan secara menyelutuh dapat mendorong seseorang untuk turut serta mewujudkan tanggung jawabnya dalam memenuhi kewajiban perpajakannya. Hal ini sejalan dengan Wulandari(2015) yang menemukan bahwa sebagian besar wajib pajak sudah memiliki kesadaran yang cukup tinggi. Dimana wajib pajak tidak memerlukan dorongan maupun teguran dari kerabat dan keluarga dalam membayar pajak. Karena wajib sudah mengerti akan pentingnya membayar pajak dan akibat tidak membayar pajak yaitu akan merugikan negara dan menghambat pembangunan nasional. Begitu juga dengan hasil penelitian yang dilakukan oleh Setyowati(2017) menyatakan bahwa semakin baik kesadaran wajib pajak akan meningkatkan kepatuhan wajib pajak. Wajib pajak yang mengetahui akan fungsi dan tujuan pembayaran pajak serta kesungguhan melaksanakan kewajiban perpajakannya secara baik tentunya akan meningkatkan kepatuhan wajib pajak dalam membayar pajak. 


\subsection{Pengaruh Sosialisasi Perpajakan Terhadap Kepatuhan Wajib Pajak Orang Pribadi Dalam Melaporkan SPT Tahunan Melalui Kesadaran Perpajakan}

Berdasarkan hasil pengujian path coefficients dapat diketahui bahwa kesadaran perpajakan merupakan varabel yang dapat menginterveningkan pengaruh sosialisasi perpajakan terhadap kepatuhan wajib pajak orang pribadi dalam melaporkan SPT Tahunan di KPP Pratama Jayapura. Hasil uji path coefficients menunjukkan bahwa dengan adanya variabel kesadaran perpajakan yang mengintervening pengaruh sosialisasi perpajakan terhadap kepatuhan wajib pajak memberikan nilai total efek yang lebih tinggi yaitu 0,480 jika dibandingkan dengan nilai pengujian antara sosialisasi perpajakan terhadap kepatuhan wajib pajak sebesar 0,207. Hal ini dapat menjelaskan bahwa sosialisasi perpajakan memiliki pengaruh besar apabila melalui kesadaran perpajakan, ini berarti sosialisasi perpajakan dapat lebih meningkatkan kepatuhan wajib pajak apabila wajib pajak tersebut menyadari mengenai hak dan kewajiban serta peraturan dan tata cara perpajakan yang berlaku.

Hanya dengan sosialisasi tanpa ada kesadaran dari wajib pajak sebesar 0,207. Sehingga dalam menjalankan sosialisasi diharapkan KPP Pratama Jayapura benar-benar berusaha sebaik dan seefektif mungkin agar dapat meningkatkan kesadaran wajib pajak yang nantinya akan membuat wajib pajak menjadi patuh terhadap peraturan perpajakan yang berlaku. Hal ini sejalan dengan Puspita (2016) dan Astuti (2017) yang menyatakan bahwa kesadaran perpajakan dapat dijadikan variabel intervening sosialisasi terhadap kepatuhan wajib pajak.

\section{PENUTUP}

\subsection{Kesimpulan}

Berdasarkan hasil analisis dan pembahasan penelitian menganai pengaruh sosialisasi perpajakan, tarif pajak, sanksi perpajakan dan kesadaran perpajakan terhadap kepatuhan pelaporan SPT tahunan wajib pajak orang pribadi pada KPP Pratama Jayapura, dapat disimpulkan bahwa :

a. Variabel sosialisasi perpajakan berpengaruh terhadap kesadaran perpajakan SPT tahunan wajib pajak orang pribadi di KPP Pratama Jayapura.

b. Variabel sosialisasi perpajakan berpengaruh terhadap kepatuhan pelaporan SPT tahunan wajib pajak orang pribadi di KPP Pratama Jayapura.

c. Variabel tarif pajak berpengaruh terhadap kepatuhan pelaporan SPT tahunan wajib pajak orang pribadi di KPP Pratama Jayapura.

d. Variabel sanksi perpajakan tidak berpengaruh terhadap kepatuhan pelaporan SPT tahunan wajib pajak orang pribadi di KPP Pratama Jayapura.

e. Variabel kesadaran perpajakan berpengaruh terhadap kepatuhan pelaporan SPT tahunan wajib pajak orang pribadi di KPP Pratama Jayapura.

f. Variabel kesadaran perpajakan dapat mengintervening sosialisasi perpajakan terhadap kepatuhan pelaporan SPT tahunan wajib pajak orang pribadi di KPP Pratama Jayapura.

\subsection{Keterbatasan Penelitian}

Penelitian ini masih jauh dari sempurna mengingat masih banyak keterbatasan-keterbatasan antara lain, penelitian ini hanya menggunakan 1 objek penelitian yaitu wajib pajak orang pribadi dan hasil pembagian kuesioner banyak yang tidak kembali, hal ini dikarenakan aktivitas beberapa responden yang cukup padat sehingga tidak dapat mengisi kuesioner. 


\subsection{Saran}

Beberapa saran yang dapat disampaikan berdasarkan hasil penelitian ini adalah sebagai berikut :

a. Penelitian berikutnya disarankan untuk menggunakan sampel yang lebih besar dengan objek penelitian yang lebih luas misalnya wajib pajak badan, agar penelitian dapat digeneralisasi lebih luas.

b. Penelitian selanjutnya dapat mengembangkan penelitian ini dengan menambah variabel lain yang belum diekspos dalam penelitian ini. Misalnya untuk variabel lain yaitu kualitas pelayanan fiskus, pemahaman perpajakan, pengetahuan perpajakan, dan sistem perpajakan untuk dapat meningkatkan tingkat kepatuhan wajib pajak dimasa yang akan datang.

c. KPP Pratama Jayapura harus lebih aktif dalam memberikan informasi kepada wajib pajak untuk mengikuti sosialisasi, serta upaya-upaya yang dilakukan dalam sosialisasi dalam bentuk penyuluhan, dan penjelasan kepada seluruh masyarakat yang menjadi wajib pajak ditingkatkan dan lebih intensif. 


\section{DAFTAR PUSTAKA}

Ananda, P. R. D., Kumadji, S., \& Husaini, A. (2015). Pengaruh Sosialisasi Perpajakan, Tarif Pajak, dan Pemahaman Perpajakan terhadap Kepatuhan Wajib Pajak (Studi pada UMKM yang Terdaftar sebagai Wajib Pajak di Kantor Pelayanan Pajak Pratama Batu). Jurnal Perpajakan (JEJAK), 6(9), 1689-1699. https://doi.org/10.1017/CBO9781107415324.004

Andreas, \& Savitri, E. (2015). The Effect of Tax Socialization, Tax Knowledge, Expediency of Tax ID Number and Service Quality on Taxpayers Compliance with Taxpayers Awareness as Mediating Variables. Procedia - Social and Behavioral Sciences, 211(September), 163-169. https://doi.org/10.1016/j.sbspro.2015.11.024

Andriani, Y., Herianti, E. (2015). Pengaruh Sosialisasi Pajak, Pemahaman Perpajakan, dan Tingkat Pendidikan Terhadap Kepatuhan Wajib Pajak UMKM (Studi empiris UMKM di Pasar Tanah Abang, Jakarta Tahun 2013-Agustus 2015). Seminar Nasional Dan 3rd Call for Syariah Paper: Menakar Peran Profesi Sebagai Engine of Reform Dalam Pembangunan Global Berkelanjutan, 487-496.

Anonim, 2017.www.pajak.go.id/content/article/penerimaan-pajak-non-pph-migas-2016-tumbuh2915.

Arum, H. P. (2012). Pengaruh Kesadaran Wajib Pajak, Pelayanan Fiskus, dan Sanksi Pajak Terhadap Kepatuhan Wajib Pajak Orang Pribadi yang Melakukan Kegiatan Usaha dan Pekerjaan Bebas (Studi di Wilayah KPP Pratama Cilacap), 1-63.

Astuti, P. T. (2017). Pengaruh Sosialisasi, Pengetahuan Pajak, dan Kualitas Pelayanan Terhadap Tingkat Kepatuhan Pajak Bumi dan Bangunan dengan Kesadaran Sebagai Variabel Intervening (Studi Pada Wajib Pajak Bumi dan Bangunan di Kabupaten Sukoharjo), 1-158.

Burhan, H. P. (Universitas D. (2015). Pengaruh Sosialisasi Perpajakan, Pengetahuan Perpajakan, Persepsi Wajib Pajak Tentang Sanksi Pajak dan Implementasi PP Nomor46 Tahun 2013 Terhadap Kepatuhan Wajib Pajak Orang Pribadi (Studi Empiris pada Wajib Pajak di Kabupaten Banjanegara). Skripsi FE Undip, 65.

Dharma, G. P. E., \& Suardana, K. A. (2014). Pengaruh Kesadaran Wajib Pajak, Sosialisasi Perpajakan, Kualitas Pelayanan Pada Kepatuhan Wajib Pajak. E-Jurnal Akuntansi Universitas Udayana, 1, 340-353.

Ghazali, I (2014). Structural Equation Modeling. Dalam Metode Alternatif dengan Partial Least Square (PLS). Semarang: Badan Penerbit Universitas Dipenegoro Semarang.

Giri, M.D. (2014). Pengaruh Partisipasi Penganggaran pada Kinerja Manajerial dengan Keadilan Distributif, Keadilan Prosedural, dan Komitmen Tujuan Anggaran Sebagai Variabel Pemediasi. Diambil kembali dari: https://median.neliti.com/media/publications/44688-ID-keadilandistributif-keadilan-prosedural-dan-komitmen-tujuan-anggaran-sebagai-pe.pdf

Jatmiko, A. N. (2006). Pengaruh Sikap Wajib Pajak Pada Pelaksanaan Sanksi Denda, Pelayanan Fiskus dan Kesadaran Perpajakan Terhadap Kepatuhan Wajib Pajak( Studi Empiris Terhadap Wajib Pajak Orang Pribadi di Kota Semarang ).

Julianti, M. (2014). Analisis Faktor-faktor yang Mempengaruhi Kepatuhan Wajib Pajak Orang Pribadi Untuk Membayar Pajak Dengan Kondisi Keuangan dan Preferensi Risiko Wajib Pajak Sebagai Variabel Moderating (Studi Kasus pada Wajib Pajak yang Terdaftar di KPP Pratama Candisari S, 1-82. 
Kristanty, N., Khairani, S., \& Fajriana, I. (2014). Pengaruh Pengetahuan Wajib Pajak, Tarif Pajak, dan Penyuluhan Pajak Terhadap Tingkat Kepatuhan Wajib Pajak Badan di Kantor Pelayanan Pajak Madya Palembang, 1-12.

Mahmud, Muhammad, A., \& Syukriy, A. (2017). Pengaruh Pemahaman Peraturan Perpajakan, Kesadaran Membayar Pajak dan Kualitas Pelayanan Perpajakan Terhadap Kepatuhan Wajib Pajak Badan ( Studi Empiris Pada Koperasi Di Kota Banda Aceh ). Jurnal Magister Akuntansi, $6(2), 32-40$.

Mardiasmo. 2011. Perpajakan. Edisi Revisi. Yogyakarta: Andi.

Mutia, S. P. T. (2014). Pengaruh Sanksi Perpajakan, Kesadaran Perpajakan, Pelayanan Fiskus, dan Tingkat Pemahaman terhadap Kepatuhan Wajib Pajak Orang Pribadi (Studi Empiris pada Wajib Pajak Orang Pribadi yang Terdaftar di KPP Pratama Padang). E-Perpajakan, 1-30. Retrieved from http://ejournal.unp.ac.id/students/index.php/akt/article/viewFile/902/652

Pris, A. (2010). Dampak Dimensi Keadilan Pajak Terhadap Tingkat Kepatuhan Wajib Pajak Badan, $1-97$.

Puspita, E. (2016). Analisis Jalur Pengaruh Sosialisasi Terhadap Kepatuhan Wajib Pajak Bumi dan Bangunan Kota Kediri Dengan Kesadaran Sebagai Variabel Intervening. Jurnal Akuntansi \& Ekonomi, 1(1), 1-8.

Rohmawati, A. N., \& Rasmini, N. K. (2012). Pengaruh Kesadaran, Penyuluhan, Pelayanan, dan Sanksi Perpajakan Pada Kepatuhan Wajib Pajak Orang Pribadi. Jurnal Akuntansi, 1-17.

Saad, N. (2014). Tax Knowledge, Tax Complexity and Tax Compliance: Taxpayers' View. Procedia - Social and Behavioral Sciences, 109(1), 1069-1075. https://doi.org/10.1016/j.sbspro.2013.12.590

Savitri, E., \& Musfialdy. (2016). The Effect of Taxpayer Awareness, Tax Socialization, Tax Penalties, Compliance Cost at Taxpayer Compliance with Service Quality as Mediating Variable. Procedia - Social and Behavioral Sciences, 219, 682-687. https://doi.org/10.1016/j.sbspro.2016.05.051

Septiani, M., Sirajuddin, B., \& Sugara, K. (2013). Pengaruh Administrasi, Sosialisasi Dan Implementasi Peraturan Pemerintah Nomor 46 Tahun 2013 Terhadap Kepatuhan Wajib Pajak Dalam Membayar Pajak UKM ( Studi Kasus : KPP Pratama Ilir Barat I Palembang ), (46), 110.

Setiyoningrum, A. T., Tinangon, J., \& Wokas, H. R. . (n.d.). Analisis Pengaruh Sosialisasi Perpajkan, Kualitas Pelayanan Fiskus dan Sanksi Perpajakan Terhadap Kepatuhan Wajib Pajak Orang Pribadi di Kantor Pelayanan Pajak Pratama Manado, 50-62.

Setyowati, Y. (2017). Pengaruh Pengetahuan Perpajakan, Sanksi Pajak dan Kesadaran Wajib Pajak Terhadap Kepatuhan Wajib Pajak Orang Pribadi Dalam Membayar Pajak Bumi Dan Bangunan Di Desa Kalidengen, Kecamatan Temon, Kabupaten Kulon Progo Tahun 2014. Jurnal Profita, $1-21$.

Sukmana, yoga. "Per Agustus 2017, Realisasi Penerimaan. Pajak Hanya 53,5 Persen.” Kompas.com. Ed. Muhammad Fajar Marta. 4 Sept.2017

Suhendri, D. (2015). Pengaruh Pengetahuan, Tarif Pajak, dan Sanksi Pajak Terhadap Kepatuhan Wajib Pajak Orang Pribadi yang Melakukan Kegiatan Usaha dan Pekerjaan Bebas di Kota Padang (Studi Empiris pada Kantor Pelayanan Pajak Pratama Kota Padang), 31. 
Syahriah. "Penerimaan Pajak di KPP Pratama Jayapura Mencapai Rp.1,350 Triliun.”

KabarPapua.co. 7 Nov.2017

Tawas, V. B. J., Poputra, A. T., \& Lambey, R. (2016). Pengaruh Sosialisasi Perpajakan, Tarif Pajak, Dan Sanksi Perpajakan Terhadap Kepatuhan Pelaporan SPT Tahunan Wajib Pajak Orang Pribadi (Studi Kasus Pada KPP Pratama Bitung). Jurnal EMBA, 4(4), 912-921.

Tene, H. J., Sondakh, J. J., \& Warongan, J. D. (2017). "Pengaruh Pemahaman Wajib Pajak, Kesadaran Pajak, Sanksi Perpajakan Dan Pelayanan Fiskus Terhadap Kepatuhan Wajib Pajak (Studi Epiris Pada Wajib Pajak Orang Pribadi Yang Terdaftar di KPP Pratama Manado).” 443 Jurnal EMBA, 5(2), 443-453.

Tiraada, T. A. . (2013). Kesadaran Perpajakan,Sanksi Pajak,Sikap Fiskus Terhadap Kepatuhan WPOP Di Kabupaten Minahasa Selatan. Emba, 1(3), 999-1008. https://doi.org/10.1017/CBO9781107415324.004

Tologana, E. Y. (2015). Pengaruh Sanksi, Motivasi dan Tingkat Pendidikan terhadap Kepatuhan Wajib Pajak Orang Pribadi (Studi Kasus KPP Pratama Manado).

Veronica, A. (2015). Pengaruh Sosialisasi Perpajakan, Pelayanan Fiskus, Pengetahuan Pajak, Persepsi Pengetahuan Korupsi, dan Sanksi Perpajakan terhadap Kepatuhan Wajib Pajak Orang Pribadi ( WPOP ) pada KPP Pratama Senapelan Pekanbaru. Jom. FEKON, 2, 1-15.

Warouw, J. Z. S., Sondakh, J. J., \& Walandouw, S. K. (2015). Pengaruh Sosialisasi Perpajakan Dan Sanksi Perpajakan Terhadap Kepatuhan Pelaporan SPT Tahunan Wajib Pajak Badan (Studi Kasus Pada KPP Pratama Manado Dan KPP Pratama Bitung). Jurnal EMBA, 3(4), 585-592.

Widiastuti, D., Astuti, E. S., \& Susilo, H. (2013). Pengaruh Sosialisasi, Motivasi, dan Pemahaman Wajib Pajak Terhadap Kepatuhan Wajib Pajak (Studi Pada Pengusaha Kena Pajak di Kantor Pelayanan Pajak Pratama Malang Utara). Journal Perpajakan, 1-9.

Wirenungan, O. L. (2013). Sosialisasi Perpajakan, Pelayanan Fiskus dan Sanksi Perpajakan terhadap Kepatuhan WPOP di KPP Manado dan KPP Bitung. Jurnal EMBA, 1(3), 960-970. https://doi.org/ISSN 2303-1174

Wulandari, T. (2015). Pengaruh Sosialisasi Perpajakan, Pengetahuan Perpajakan, dan Kualitas Pelayanan Terhadap Kepatuhan Wajib Pajak dengan Kesadaran Wajib Pajak Sebagai Variabel Intervening (Studi Pada Kantor Pelayanan Pajak Pratama Pekanbaru Senapelan), 1-15.

Yuwono, Z. D. (2015). Pengaruh Sosialisasi Terhadap Kesadaran dan Kepatuhan Wajib Pajak Bumi dan Bangunan di Kota Kediri, 1-13. 